\title{
PENGARUH JENIS DAN KONSENTRASI ENKAPSULAN DALAM PROSES PEMBUATAN SERBUK ANTOSIANIN DARI KUBIS MERAH DAN BUNGA TELANG
}

\author{
(The effects of encapsulant type and concentration in the making of \\ powdered anthocyanin from red cabbage and butterfly pea)
}

\author{
Novita Ika Putri ${ }^{a *}$, Melvern Jan Chance ${ }^{a}$, Priska Adina Chandra Rahardjo ${ }^{a}$, \\ Victoria Kristina Ananingsih ${ }^{a}$
}

${ }^{a}$ Fakultas Teknologi Pertanian, Universitas Katolik Soegijapranata, Semarang, Indonesia

${ }^{*}$ Penuliskorespondensi

Email: novitaika@unika.ac.id

\begin{abstract}
The usage of natural colorants in the food industry keeps increasing due to their health-promoting abilities. Natural ingredients that have the potential to be developed into natural colorants are red cabbage (Brassica oleraceavar. capitate f. rubra) and butterfly pea flower (Clitoria ternatea). These two ingredients have a high anthocyanin pigment content, but this pigment is easily degraded by heat and pH.Encapsulation process using maltodextrin and soy protein isolates were expected to be able to maintain the anthocyanin stability. This research aimed to study the effects of encapsulant types (maltodextrin and soy protein isolates) and concentration $(55,10 \%, 15 \%)$ on the physical and chemical characteristics of natural colorant powder from red cabbage and butterfly pea flower. Water content, total anthocyanin content, solubility, and thermal stability at temperature $300 \mathrm{C}, 600 \mathrm{C}, 100 \mathrm{oC}$ were tested. Results showed that the usage of maltodextrin as an encapsulant tends to produce a purplish powder while soy protein isolate tends to produce powder with bluish color. Increasing concentration of maltodextrin caused not only a decrease on the total anthocyanin content and antioxidant activity, but also an increase on yield, lightness, color intensity and solubility. Meanwhile, increasing concentration of soy protein isolates caused an increase on yield, and blue color intensity, however it also caused a decrease on the anthocyanin content, antioxidant activity, lightness and solubility. Overall, natural colorant powder made using 5\% maltodextrin showed optimum protection on the anthocyanin.
\end{abstract}

Keywords: natural colorant, powder, red cabbage, butterfly pea

\begin{abstract}
ABSTRAK
Penggunaan pewarna alami di bidang pangan terus meningkat karena sifatnya yang memiliki efek yang baik bagi kesehatan. Bahan alami yang mempunyai potensi untuk dikembangkan sebagai pewarna alami antara lain kubis merah (Brassica oleraceavar. capitate f. rubra) dan bunga telang (Clitoria ternatea). Kedua bahan tersebut memiliki kandungan pigmen antosianin yang tinggi, namun pigmen ini mudah terdegradasi oleh panas dan $\mathrm{pH}$. Proses enkapsulasi menggunakan bahan maltodekstrin dan isolate protein kedelai diharapkan dapat menjaga kestabilan antosianin serbuk kubis merah dan bunga telang. Penelitian ini bertujuan untuk mengetahui pengaruh penambahan bahan enkapsulan(maltodekstrin dan isolate protein kedelai) pada berbagai konsentrasi $(5 \%, 10 \%$ dan $15 \%)$ terhadap karakteristik fisik dan kimia serbuk pewarna ekstrak kubis merah dan bunga telang. Analisa fisiokimia yang dilakukan meliputi pengukuran kadar air, analisa total antosianin, analisa aktivitas antioksidan, daya larut, dan stabilitas warna pada suhu $30^{\circ} \mathrm{C}, 60^{\circ} \mathrm{C}$ dan $100^{\circ} \mathrm{C}$. Hasil penelitian menunjukkan bahwa penggunaan enkapsulan maltodekstrin mempunyai kecenderungan menghasilkan serbuk dengan warna ungu dan isolat protein kedelai akan menghasilkan warna biru. Peningkatan konsentrasi maltodekstrin akan menyebabkan
\end{abstract}


penurunan total antosianin dan aktivitas antioksidan, namun menyebabkan peningkatan rendemen, kecerahan warna $\left(L^{*}\right)$, intensitas warna $\left(a^{*}\right.$ dan $\left.b^{*}\right)$, serta kelarutan. Selain itu, untuk serbuk pewarna dengan enkapsulan berupa isolat protein kedelai, peningkatan konsentrasi isolat protein kedelai menyebabkan peningkatan rendemen, serta intensitas warna $\left(b^{*}\right)$, namun menyebabkan penurunan total antosianin, aktivitas antioksidan, kecerahan warna, intensitas warna $\left(a^{*}\right)$, serta kelarutan. Serbuk pewarna dengan maltodekstrin 5\% mampu melindungi antosianin dalam ekstrak secara optimum.

Kata kunci: pewarna alami, serbuk, kubis merah, bunga telang

\section{PENDAHULUAN}

Tren penggunaan bahan-bahan natural dan bahan yang memiliki efek baik bagi kesehatan di bidang pangan terus meningkat. Hal ini memicu pengurangan konsumsi bahan tambahan pangan yang bersifat sintetis dan dikembangkannya bahan alternative seperti bahan pewarna alami. Bahan pangan yang memiliki potensi sebagai bahan pewarna alami antara lain kubis merah (Brassica oleracea var. capitate f. rubra) dan bunga telang (Clitoria ternatea). Kedua bahan tersebut memiliki kandungan senyawa antosianin yang tinggi, yaitu sebesar 104-188 mg/100g kubis merah segar (Ahmadiani, Robbins, Collins, \& Giusti, 2015) dan 22,74 mg/100 g bunga telang segar (Vankar \& Srivastava, 2010). Antosianin merupakan pigmen yang dapat ditemukan secara alami pada bahan pangan, memiliki sifat antioksidatif dan dapat memberikan warna merah-biru (Ahmadiani et al., 2015). Meskipun demikian, ekstrak antosianin yang didapatkan dari kubis merah dan bunga telang memiliki kelemahan, yaitu tidak stabil akibat $\mathrm{pH}$, suhu dan penyimpanan(Vankar \& Srivastava, 2010). Oleh karena itu, ekstrak antosianin yang diperoleh dari kubis merah dan bunga telang perlu dienkapsulasi agar stabil selama penyimpanan dan dapat diaplikasikan sebagai serbuk pewarna alami.

Enkapsulan juga memiliki fungsi sebagai pelindung antosianin dari panas yang biasanya digunakan selama proses pembuatan serbuk pewarna alami. Bahan enkapsulan yang telah banyak diaplikasikan antara lain maltodekstrin (MD) dan isolate protein kedelai (IPK). MD mampu mengurangi degradasi antosianin akibat panas pada daun jati dan bunga rosela (Ernawati,2010; Ernawatiet al.,2014), sedangkan IPK telah digunakan dalam enkapsulasi minyak kelapa sawit, oleoresin paprika dan lain sebagainya (Hasrini et al,. 2017; Paola, Beristain, García, \& Salgado, 2011).

Penelitian ini bertujuan untuk menentukan pengaruh jenis dan konsentrasi enkapsulan dalam proses pembuatan pewarna serbuk antosianin yang diesktrak dari kubis merah dan bunga telang. Diharapkan dari hasil penelitian ini, dapat dikembangkan serbuk pewarna alami yang dapat diaplikasikan untuk berbagai jenis produk sebagai alternatif pewarna sintetis.

\section{BAHAN DAN METODE}

\section{Bahan}

Bahan yang digunakan dalam penelitian ini adalah kubis merah, bunga telang kering, maltodextrin DE-10, isolate protein kedelai dengan kadar protein $73,27 \%$, asam sitrat $1 \%$, methanol $99,98 \%$ (E. Merck), DPPH (Sigma Aldrich), $\mathrm{HCl}$ pekat (E. Merck), dan $\mathrm{CH}_{3} \mathrm{COONa}$ (E. Merck).

\section{Preparasi kubis merah dan bunga telang}

Pigmen dalam kubis merah dan bunga telang diekstraksi terlebih dahulu. Proses ekstraksi dilakukan dengan merendam bahan pada larutan asam sitrat $1 \%$ dengan rasio bahan : pelarut yaitu 1:4. Ekstraksi dilakukan selama 6 jam pada suhu ruang dalam ruang gelap. Bahan yang telah diekstrak kemudian disaring menggunakan 
kain saring dan diperoleh ekstrak pewarna alami kubis merah dan bunga telang.

\section{Metode pembuatan serbuk pewarna alami}

Ekstrak kubis merah dan bunga telang dicampur dengan bahan penyalut berupa maltodekstrin atau isolat protein kedelai dengan konsentrasi $5 \%$, 10\%, dan 15\% (b/b). Pencampuran dilakukan dengan proses homogenisasi menggunakanstirrer pada kecepatan 1000 rpm selama 10 menit.Larutan yang telah homogen kemudian dikeringkan menggunakan metode cabinet dryingpada suhu $60^{\circ} \mathrm{C}$ selama 12 jam. Bahan yang telah kering kemudian dihaluskan dengan blender, diayak dengan ayakan 80 mesh.

\section{Analisa Sifat Fisik}

Pengujian rendemen serbuk pewarna alami kubis merah dinyatakan sebagai rasio berat campuran ekstrak pewarna dan enkapsulan awaldengan hasil serbuk yang dihasilkan (Hayati et al., 2015). Pengujian kadar air dilakukan dengan metode termogravimetri sesuai dengan metode Sudarmadji et al. (1984). Intensitas warna dianalisa dengan Chromameter CR-400 dan nilai warna dinyatakan dalam bentuk $L^{*}$, $a^{*}$ dan $b^{*}$.

Kelarutan serbuk dalam air diuji dengan menggunakan metode dari Yuwono \& Susanto dalam Mulyadi et al., (2013). Mulamula kertas saring dioven selama 10 menit pada suhu $105^{\circ} \mathrm{C}$ dan ditimbang hingga berat konstan (a). Sampel serbuk pewarna alami kubis merah ditimbang sebanyak 1 gram (berat awal) kemudian dimasukkan ke dalam air dengan volume $20 \mathrm{ml}$ pada suhu $25^{\circ} \mathrm{C}$. Selanjutnya larutan tersebut disaring menggunakan kertas saring yang telah ditimbang. Kertas saring yang telah digunakan kemudian dioven kembali selama 3 jam pada suhu $105^{\circ} \mathrm{C}$ dan ditimbang hingga beratnya konstan (b). Kelarutan dalam air atau daya larut serbuk dihitung dengan rumus :(b-a) / berat awal * $100 \%$.

\section{Analisa Total Antosianin}

Pengujian total antosianin dilakukan dengan metode AOAC (2005) yang dimodifikasi. Pengukuran dilakukan menggunakan metode $\mathrm{pH}$ diferensial. Kandungan total antosianin akan dinyatakan sebagai cyanidin-3-glycoside. Sampel serbuk pewarna alami dilarutkan menggunakan aquades dengan perbandingan 1:10 dan diambil sebanyak $0,2 \mathrm{ml}$ lalu diencerkan dengan buffer $\mathrm{pH} 1$ dan $\mathrm{pH} 4,5$ sebanyak $1,8 \mathrm{ml}$. Selanjutnya diukur absorbansi kedua sampel tersebut dengan panjang gelombang $520 \mathrm{~nm}$ serta $700 \mathrm{~nm}$. Selisih nilai absorbansi untuk masing-masing $\mathrm{pH}$ kemudian dihitung. Kadar total antosianin monomerik yang dinyatakan sebagai cyanidin-3-glycoside (mg/L) dapat dihitung dengan rumus :

$(A \times M W \times D F \times 1000) /(\varepsilon \times I)$

Keterangan :

$\mathrm{A}=$ selisih nilai absorbansi

$\mathrm{MW}$ = berat molekul cyanidin-3-glycoside $(449,2 \mathrm{~g} / \mathrm{mol})$

DF = faktor pengenceran (10)

$\varepsilon=$ absorptivitas molar cyanidin-3-glycoside $(26.900 \mathrm{~L} / \mathrm{cm} \mathrm{mol})$

$\mathrm{I}=$ lebar kuvet $(1 \mathrm{~cm})$

\section{Analisa Aktivitas Antioksidan}

Aktivitas antioksidan dihitung dengan menggunakan metode dari Apriyantono et al. (1989). Sebanyak 0,5 gram serbuk pewarna alami diekstrak menggunakan metanol 99,98\% sebanyak $5 \mathrm{ml}$ selama 2 jam. Ekstrak yang didapatkan direaksikan dengan larutan DPPH. Aktivitas antioksidan akan dinyatakan sebagai \%discoloration.

\section{Analisa Stabilitas Pewarna}

Stabilitas serbuk pewarna alami kubis merah dan bunga telang diuji dalam 3 tingkat suhu yaitu suhu ruang $30^{\circ} \mathrm{C}, 60^{\circ} \mathrm{C}$, dan $100^{\circ} \mathrm{C}$. Sampel serbuk pewarna alami kubis merah dengan total antosianin tertinggi dilarutkan dalam aquades dengan perbandingan 1:10 kemudian diambil sebanyak $2 \mathrm{ml}$ dan dilarutkan dalam $100 \mathrm{ml}$ aquades. Setelah itu larutan dipanaskan 
pada ketiga tingkat suhu tersebut selama 1 jam. Kemudian volume larutan dikembalikan ke volume awal dengan ditambahkan aquades suhu pemanasan. Selanjutnya absorbansi larutan diukur menggunakan spektrofotometer dengan panjang gelombang 400 hingga $600 \mathrm{~nm}$ (Lydia et al., 2001).

\section{Analisis Statistik}

Data hasil pengujian dianalisa dengan SPSS for Windows versi 20 pada tingkat kepercayaan 95\% Metode analisa yang digunakan adalah One Way Anova. Jika ditemukan adanya perbedaan signifikan, data dianalisa lebih lanjut menggunakan uji Duncan.

\section{HASIL DAN PEMBAHASAN}

Tabel 1 menunjukkan peningkatan jumlah rendemen akibat penambahan enkapsulan MD dan IPK. MD dan IPK akan menambah jumlah total padatan dan bertindak sebagai filler sehingga meningkatkan rendemen. Kadar air dari serbuk pewarna alami yang dihasilkan lebih rendah dari $12 \%$, sehingga serbuk yang dihasilkan memiliki umur simpan yang cukup panjang.

Pada Tabel 2, hasil penelitian menunjukkan nilai kelarutan dari serbuk pewarna alami yang dihasilkan. Baik pada kubis merah maupun bunga telang, serbuk yang dibuat dengan MD sebagai enkapsulan memiliki kelarutan yang jauh lebih baik dibandingkan dengan IPK. Hal ini disebabkan oleh $\mathrm{pH}$ ekstrak pewarna alami yang rendah. IPK memiliki kelarutan yang baik pada $\mathrm{pH}$ basa. Namun ketika $\mathrm{pH}$ semakin asam dan mendekati titik isoelektrik IPK ( $\mathrm{pH} 4,5)$, maka kelarutan IPK akan berkurang secara signifikan hingga mendekati 0 (Molina \& Wagner, 2002). Hasil yang sama juga diperoleh pada penelitian sebelumnya, di mana MD akan memiliki kelarutan yang lebih baik karena polaritasnya yang lebih besar, sedangkan interaksi IPK dengan antosianin menyebabkan gugus non-polar dalam sistem meningkat dan mengurangi kelarutan (Cardinale, Souza, Gurak, Damasceno, \& Marczak, 2016).

Warna serbuk pewarna alami merupakan parameter yang sangat krusial. Hasil analisa warna dapat dilihat oada Tabel 2. MD memberikan warna yang lebih cerah dibandingkan dengan IPK. Semakin banyak MD yang ditambahkan, Lightness akan semakin besar, sebaliknya semakin banyak IPK yang ditambahkan warna akan semakin gelap. MD akan menambah jumlah total padatan dan karena warnanya yang putih, MD memberikan efek pemudaran warna. Hasil yang sama juga diperoleh pada penelitian sebelumnya (Thomazini, Balieiro, Piccone, \& Comunian, 2011).

Berdasarkan nilai $a^{*}$ dan $b^{*}$ pada Tabel 2 , hasil pewarna kubis merah memiliki warna merah keunguan, sedangkan bunga telang memiliki warna lebih kebiruan. Semakin banyak konsentrasi MD dan IPK yang ditambahkan tidak mempengaruhi nilai $a^{*}$ dan $b^{*}$ secara signifikan.

Kandungan total antosianin, pigmen pada serbuk pewarna alami, mengalami penurunan yang cukup signifikan akibat penambahan bahan enkapsulan. Penurunan kandungan antosianin ini diikuti dengan menurunnya aktivitas antioksidan. Sifat antioksidatif serbuk pewarna alami sebagian berasal dari pigmen antosianin, sehingga total antosianin dan aktivitas antioksidan berbanding lurus. Kandungan total antosianin dan aktivitas antioksidan serbuk pewarna alami kubis merah lebih tinggi dibandingkan dengan bunga telang. Hal ini sesuai dengan jumlah antosianin awal pada kubis merah dan bunga telang.

MD mampu melindungi antosianin lebih baik dibandingkan dengan IPK (Tabel 3.). Pada proses enkapsulasi antosianin, terdapat kation flavium pada antosianin yang membentuk kompleks dengan karbohidrat dari maltodekstrin yang digunakan sehingga antosianin dapat terlindungi dengan baik(Chandra, Nair, \& lezzoni, 1993). Sementara itu, IPK tidak dapat bertindak sebagai enkapsulan yang baik untuk antosianin karena $\mathrm{pH}$ yang 
Jurnal Teknologi Pangan dan Gizi Journal of Food Technology and Nutrition Vol 18 (1): 1-9, 2019.

Tabel 1. Rendemen dan Kadar Air Serbuk Pewarna Alami dari Kubis Merah

\begin{tabular}{lccccc}
\hline \multirow{2}{*}{$\begin{array}{c}\text { Jenis } \\
\text { Enkapsulan }\end{array}$} & $\begin{array}{c}\text { Konsentrasi } \\
\text { Enkapsulan (\%) }\end{array}$ & \multicolumn{2}{c}{ KM } & BT & \multicolumn{2}{c}{ Kadar air (\%bb) } \\
\cline { 3 - 6 } Maltodekstrin & 5 & $5,417 \pm 0,118$ & $6,230 \pm 0,617$ & $7,837 \pm 0,362$ & $7,188 \pm 0,296$ \\
& 10 & $9,583 \pm 0,118$ & $10,583 \pm 0,032$ & $7,373 \pm 0,249$ & $6,699 \pm 0,266$ \\
& 15 & $13,604 \pm 0,383$ & $14,553 \pm 0,570$ & $7,220 \pm 0,205$ & $3,716 \pm 1,021$ \\
\hline \multirow{2}{*}{ Isolat Protein } & 5 & $4,833 \pm 0,118$ & $6,230 \pm 0,056$ & $3,997 \pm 0,486$ & $0,554 \pm 0,268$ \\
Kedelai & 10 & $9,583 \pm 0,236$ & $11,098 \pm 0,054$ & $6,111 \pm 0,402$ & $2,315 \pm 0,422$ \\
& 15 & $13,708 \pm 0,295$ & $16,410 \pm 0,424$ & $7,935 \pm 0,442$ & $2,634 \pm 0,825$ \\
\hline
\end{tabular}

Data dinyatakan dalam rerata \pm SD

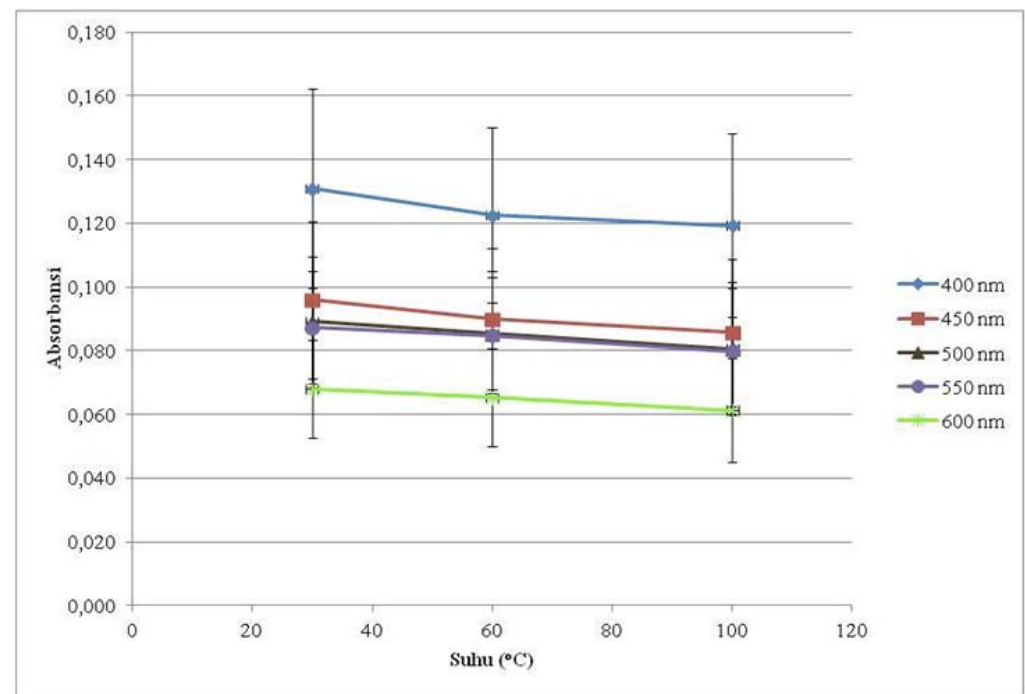

Gambar 1. Stabilitas Serbuk Pewarna Alami Kubis Merah dengan Maltodekstrin 5\% pada 3 Tingkat Suhu

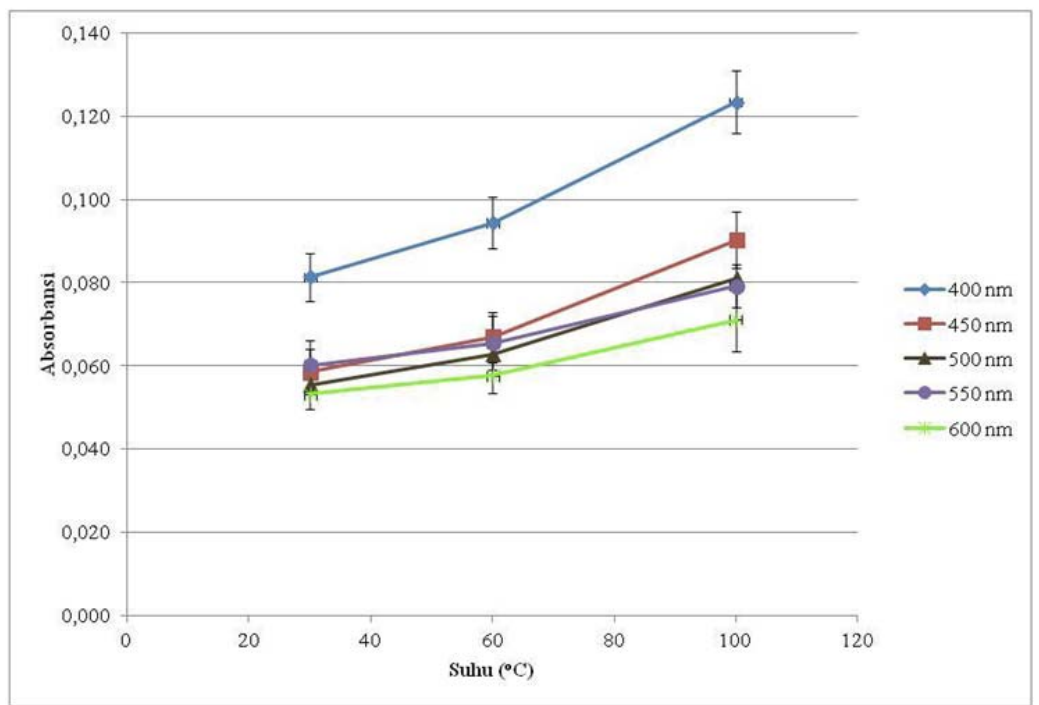

Gambar 2. Stabilitas Serbuk Pewarna Alami Kubis Merah dengan Isolat Protein Kedelai $5 \%$ pada 3 Tingkat Suhu 


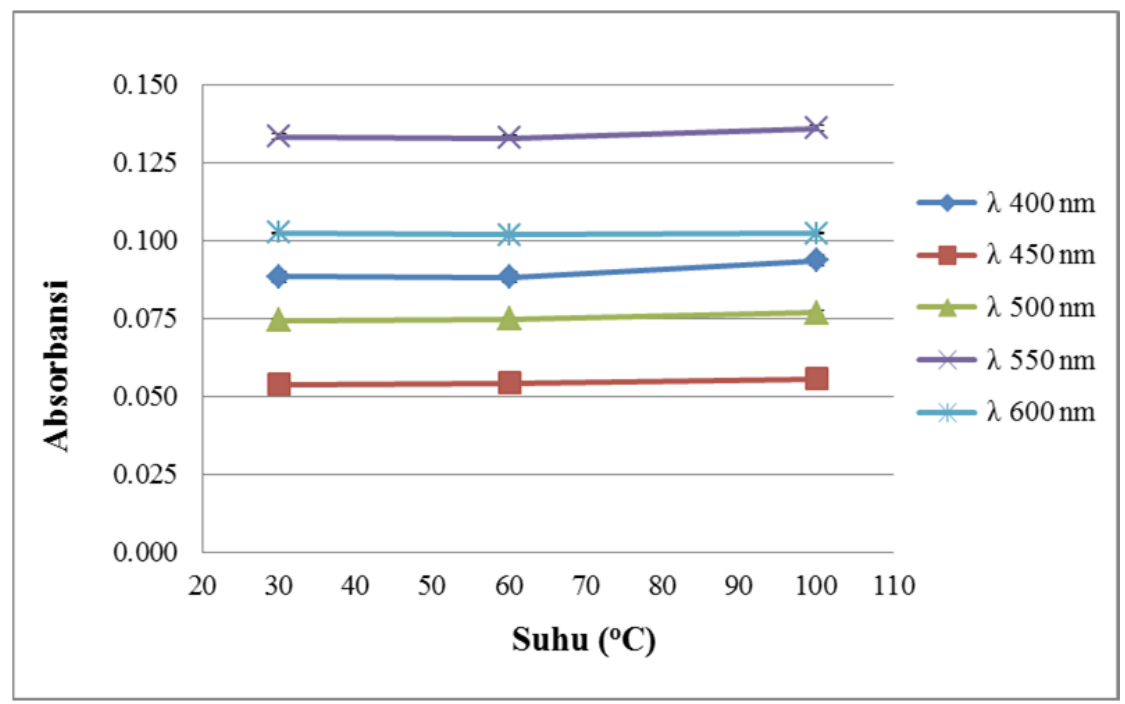

Gambar 3. Stabilitas Serbuk Pewarna Bunga Telang dengan Maltodekstrin 5\% pada 3 Tingkat Suhu

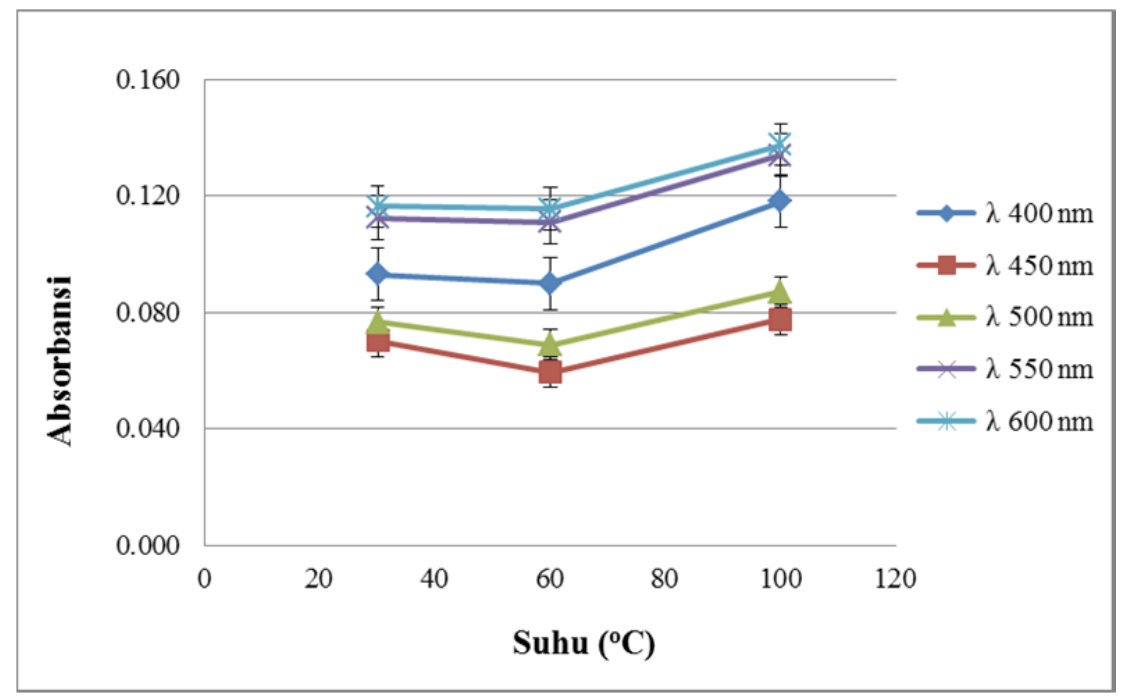

Gambar 4. Stabilitas Serbuk Pewarna Bunga Telang dengan Isolat Protein Kedelai $5 \%$ pada 3 Tingkat Suhu 
Jurnal Teknologi Pangan dan Gizi Journal of Food Technology and Nutrition Vol 18 (1): 1-9, 2019.

Tabel 2. Sifat Fisik Serbuk Pewarna Alami Kubis Merah

\begin{tabular}{|c|c|c|c|c|c|c|c|c|c|}
\hline \multirow{2}{*}{$\begin{array}{c}\text { Jenis } \\
\text { Enkapsulan }\end{array}$} & \multirow{2}{*}{$\begin{array}{c}\text { Konsentrasi } \\
\text { Enkapsulan (\%) }\end{array}$} & \multicolumn{2}{|c|}{ Kelarutan } & \multicolumn{2}{|c|}{$L^{*}$} & \multicolumn{2}{|c|}{$a^{*}$} & \multicolumn{2}{|c|}{$b^{*}$} \\
\hline & & KM & BT & $\mathrm{KM}$ & BT & $\mathrm{KM}$ & BT & KM & BT \\
\hline \multirow{3}{*}{ Maltodekstrin } & 5 & $84,017 \pm 1,570^{a}$ & $86,665 \pm 4,144^{a}$ & $46,563 \pm 1,342^{a}$ & $41,507 \pm 0,489^{a}$ & $16,867 \pm 7,532^{\mathrm{a}}$ & $19,218 \pm 1,630^{a}$ & $-1,082 \pm 0,157^{a}$ & $-1,300 \pm 0,174^{a}$ \\
\hline & 10 & $86,983 \pm 1,269^{b}$ & $86,904 \pm 2,886^{a}$ & $45,250 \pm 4,030^{a}$ & $45,628 \pm 0,208^{b}$ & $24,870 \pm 3,250^{b}$ & $19,853 \pm 1,195^{\mathrm{a}}$ & $-3,525 \pm 1,263^{b}$ & $-3,197 \pm 0,509^{b}$ \\
\hline & 15 & $88,450 \pm 1,108^{b}$ & $87,934 \pm 0,694^{a}$ & $53,148 \pm 0,760^{b}$ & $46,367 \pm 0,302^{c}$ & $23,980 \pm 5,949^{a b}$ & $20,458 \pm 1,319^{a}$ & $-2,792 \pm 1,175^{b}$ & $-3,713 \pm 0,512^{b}$ \\
\hline \multirow{3}{*}{$\begin{array}{l}\text { Isolat Protein } \\
\text { Kedelai }\end{array}$} & 5 & $25,083 \pm 1,720^{1}$ & $32,321 \pm 2,864^{1}$ & $59,970 \pm 0,569^{1}$ & $14,588 \pm 0,352^{1}$ & $13,330 \pm 1,492^{1}$ & $14,588 \pm 0,352^{1}$ & $-6,690 \pm 1,888^{1}$ & $-12,332 \pm 0,695$ \\
\hline & 10 & $21,067 \pm 0,547^{2}$ & $23,024 \pm 1,080^{2}$ & $58,405 \pm 0,990^{2}$ & $11,663 \pm 0,340^{1}$ & $9,505 \pm 0,919^{2}$ & $11,663 \pm 0,340^{2}$ & $-0,633 \pm 0,623^{2}$ & $-14,658 \pm 0,584$ \\
\hline & 15 & $20,717 \pm 1,525^{2}$ & $18,152 \pm 2,193^{3}$ & $57,610 \pm 0,446^{2}$ & $8,107 \pm 1,682^{3}$ & $8,327 \pm 0,500^{2}$ & $8,107 \pm 1,682^{1}$ & $3,197 \pm 0,567^{3}$ & $-13,148 \pm 1,417$ \\
\hline
\end{tabular}

Tabel 3. Sifat Kimia Serbuk Pewarna Alami Kubis Merah

\begin{tabular}{lccccc}
\hline \multirow{2}{*}{$\begin{array}{c}\text { Jenis } \\
\text { Enkapsulan }\end{array}$} & $\begin{array}{c}\text { Konsentrasi } \\
\text { Enkapsulan } \\
(\%)\end{array}$ & \multicolumn{2}{c}{$\begin{array}{c}\text { Kand. Total Antosianin (mg/100 g } \\
\text { serbuk) }\end{array}$} & Aktivitas Antioksidan (\%discoloration) \\
\cline { 3 - 6 } & 5 & $162,627 \pm 5,088^{\mathrm{a}}$ & $45,854 \pm 4,249^{\mathrm{a}}$ & $8,768 \pm 0,866^{\mathrm{a}}$ & $41,934 \pm 2,816^{\mathrm{a}}$ \\
Maltodekstrin & 10 & $97,509 \pm 4,989^{\mathrm{b}}$ & $31,192 \pm 5,578^{\mathrm{b}}$ & $4,174 \pm 1,257^{\mathrm{b}}$ & $27,830 \pm 2,126^{\mathrm{b}}$ \\
& 15 & $55,943 \pm 2,497^{\mathrm{c}}$ & $17,575 \pm 4,881^{\mathrm{c}}$ & $2,412 \pm 0,625^{\mathrm{c}}$ & $16,270 \pm 2,050^{\mathrm{c}}$ \\
\hline \multirow{2}{*}{ Isolat Protein } & 5 & $40,551 \pm 9,681^{1}$ & $14,851 \pm 2,633^{1}$ & $14,832 \pm 1,118^{1}$ & $23,309 \pm 4,189^{1}$ \\
Kedelai & 10 & $24,156 \pm 6,347^{2}$ & $9,946 \pm 0,625^{2}$ & $10,587 \pm 1,031^{2}$ & $10,745 \pm 0,331^{2}$ \\
& 15 & $14,511 \pm 3,807^{3}$ & $7,062 \pm 1,157^{3}$ & $6,364 \pm 1,563^{3}$ & $8,234 \pm 0,987^{2}$ \\
\hline
\end{tabular}


rendah, di mana IPK akan mengalami presipitasi (Molina \& Wagner, 2002).

Untuk aplikasi serbuk pewarna alami, stabilitas warna bila diaplikasikan pada tiga suhu diteliti. Hasil pada Gambar 1-4. menunjukkan bahwa serbuk ewarna alami dengan MD 5\% memiliki stabilitas terhadap suhu yang lebih baik, sedangkan serbuk pewarna alami dengan IPK mengalami perubahan spektrum yang lebih besar. Pada penelitian stabilitas thermal yang diakukan pada serbuk antosianin dati ekstrak Jaboticaba, ditemukan hasil yang sama (Cardinale et al., 2016). MD akan berinteraksi dengan antosianin membentuk kompleks yang stabil. Sedangkan analisa karakteristik termal pada serbuk antosianin jaboticaba menunjukkan adanya denaturasi protein yang menyebabkan ketidak-stabilan warna.

\section{KESIMPULAN}

Berdasarkan hasil penelitian yang dilakukan, dapat disimpulkan bahwa maltodekstrin merupakan bahan penyalut yang lebih baik daripada isolat protein kedelai untuk membentuk serbuk pewarna dari kubis merah dan bunga telang. Penambahan matodekstrin sebanyak 5\% pada ekstrak antosianin kubis merah dan bunga telang dapat membentuk serbuk pewarna alami yang memiliki kelarutan, profil warna, stabilitas termal, kandungan antosianin dan aktivitas antioksidan yang baik.

\section{DAFTAR PUSTAKA}

Ahmadiani, N., Robbins, R. J., Collins, T. M., \& Giusti, M. M. (2015). Anthocyanins Contents, Profiles, and Color Characteristics of Red Cabbage Extracts from Different Cultivars and Maturity Stages.

AOAC. (2005). Official Methods of Analysis (18th ed.). Maryland: AOAC International.

Apriyantono A., Fardiaz D., Puspitasari N.L.,
Yasni S., Budijanto S. (1989). Petunjuk Laboratorium Analisis Pangan. Departemen Pendidikan dan Kebudayaan Pusat Antar Universitas Pangan dan Gizi. Institut Pertanian Bogor.

Cardinale, A., Souza, P., Gurak, P. D., Damasceno, L., \& Marczak, F. (2016). MALTODEXTRIN, PECTIN AND SOY PROTEIN ISOLATE AS CARRIER AGENTS IN THE ENCAPSULATION OF ANTHOCYANINS-RICH EXTRACT FROM JABOTICABA POMACE. Food and Bioproducts Processing, 16. http://doi.org/10.1016/j.fbp.2016.12.01

2

Chandra, A., Nair, M. G., \& lezzoni, A. F. (1993). Isolation and Stabilization of Anthocyanins from Tart Cherries ( Prunus cermug $\mathrm{L}$.). Journal of Agricultural and Food Chemistry, 41(7), 1062-1065.

Ernawati, S. (2010). Stabilitas Sediaan Bubuk Pewarna Alami dari Rosela (Hibiscus sabdariffa L.) yang Diproduksi dengan Metode Spray Drying dan Tray Drying. Fakultas Teknologi Pertanian Institut Pertanian Bogor. Institut Pertanian Bogor.

Ernawati, U. R., Khasanah, L. U., \& Anandito, R. B. K. (2014). Pengaruh variasi nilai dextrose equivalents (DE) maltodekstrin terhadap karakteristik mikroenkapsulan pewarna alami daun jati (Tectona Grandis L . f .). Jurnal Teknologi Pertanian, 15(2), 111-120.

Hayati, H. R., Nugrahani, R. A., \& Satibi, L. (2015). Pengaruh konsentrasi maltodekstrin terhadap rendemen pada pembuatan santan kelapa bubuk (coconut milk powder). Seminar 
Nasional Sains dan Teknologi, 1-5.

Hasrini, R. F., Zakaria, F. R., Adawiyah, D.

R., \& Suparto, I. H. (2017).

Mikroenkapsulasi Minyak Sawit

Mentah Dengan Enkapsulan

Maltodekstrin Dan Isolat Protein

Kedelai. Jurnal Teknologi Dan Industri

Pangan, 28(1): 10-19.

Lydia, Widjanarko, S. B., \& Susanto, T. (2001). Ekstraksi dan karakterisasi pigmen dari kulit buah rambutan (Nephelium lappaceum) var. BINJAI. Jurnal Teknologi Pangan Dan Gizi, 2(1), 1-16.

Molina, S. E., \& Wagner, J. R. (2002). Hydrolysates of native and modified soy protein isolates: structural characteristics, solubility and foaming properties. Food Research International, 35, 511-518.

Mulyadi, A. F., Maligan, J. M., Wignyanto, \& Hermansyah, R. (2013). Karakteristik organoleptik serbuk perisa alami dari cangkang rajungan (Portunus pelagicus): kajian konsentrasi dekstrin dan suhu pengeringan. Jurnal Teknologi Pertanian, 14(3), 183-192.

Paola, M., Beristain, C. I., García, H. S., \& Salgado, M. A. (2011). LWT - Food Science and Technology Carotenoid retention and storage stability of spraydried encapsulated paprika oleoresin using gum Arabic and Soy protein isolate as wall materials. LWT - Food Science and Technology, 44(2), 549557.

http://doi.org/10.1016/j.Iwt.2010.08.021

Sudarmadji, S., B. Haryono, \& Suhardi. (1984). Prosedur Analisa untuk Bahan Makanan dan Pertanian (Edisi Ketiga). Yogyakarta: Liberty.

Thomazini, M., Balieiro, J. C. C., Piccone, P., \& Comunian, T. A. (2011). Original article Assessment of production efficiency, physicochemical properties and storage stability of spray-dried chlorophyllide , a natural food colourant, using gum Arabic, maltodextrin and soy protein isolatebased carrier systems. International Journal of Food Science \& Technology, 46, 1259-1265. http://doi.org/10.1111/j.1365-

2621.2011.02617.x

Vankar, P. S., \& Srivastava, J. (2010). Evaluation of Anthocyanin Content in Red and Evaluation of Anthocyanin Content in Red and Blue Flowers. International Journal of Food Engineering, 6(4), 1-11. http://doi.org/10.2202/1556-3758.1907 